\title{
Leverage of Nano-Selenium on Sexual Behavior, Reproductive Performance, Semen Characteristics, and Prophylactics in Rabbit Bucks at Hot Season
}

\author{
Ahmed A. Ali ${ }^{1}$, Shady T. Hassan ${ }^{2}$, Essam S. Soliman ${ }^{3 *}$ \\ ${ }^{1}$ Animal Behavior and Management Division, Department of Animal Hygiene, Zoonosis, and Animal Behavior, \\ Faculty of Veterinary Medicine, Suez Canal University, Ismailia 41522, Egypt; ${ }^{2}$ Department of Theriogenology, \\ Faculty of Veterinary Medicine, Suez Canal University, Ismailia 41522, Egypt. ${ }^{3}$ Animal, Poultry, and Environmental \\ Hygiene Division, Department of Animal Hygiene, Zoonosis, and Animal Behavior, Faculty of Veterinary Medicine, \\ Suez Canal University, Ismailia 41522, Egypt.
}

\begin{abstract}
Rabbit breeders seek the optimum productive and reproductive performance and high seminal characteristics in rabbit bucks. The study investigates the prophylactic influences and modifications induced by nano-selenium (NS, 0.5 and $1 \mathrm{~mL}$ ) and commercial inorganic selenium $(\mathrm{Se}, 1 \mathrm{~mL}$ ) supplementations on sexual behavior, reproductive performance, semen characteristics, antioxidant activity, testosterone hormone, and cortisol hormone levels in rabbit bucks. Twenty-four adult New Zealand white rabbit bucks of 5-months and $2.960 \mathrm{~kg}$ were individually housed in flatdeck wire cages and assigned to four groups of six bucks. The $1^{\text {st }}$ group was supplemented with one $\mathrm{mL} S e / L$, the $2^{\text {nd }}$ with $0.5 \mathrm{~mL} \mathrm{NS} / \mathrm{L}$, the $3^{\text {rd }}$ group with $1 \mathrm{~mL} \mathrm{NS} / \mathrm{L}$, and the $4^{\text {th }}$ was kept as control. A total of 384 samples were collected (120 sera, 120 plasma, and 144 semen samples), as well as bucks were evaluated for the reproductive performance, libido, semen characteristics, antioxidant activity, testosterone hormone, and cortisol hormone levels in rabbit bucks. Body weights, weight gains, feed conversion ratios, reproductive performance concerning kindling rate, and litter size and weights at birth revealed highly significant $(\mathrm{P}<0.01)$ improvements in NS supplemented bucks. Testosterone levels, reaction time, sperm mass activity, sperm individual motility, sperm concentration, normal live sperm, and normal alive motile sperms per ejaculate showed highly significant $(\mathrm{P}<0.01)$ enhancements in NS supplemented bucks. Nano-selenium supplemented bucks revealed highly significant improvement of antioxidant activity and the lowest levels of cortisol hormone. Nano-selenium $(1.0$ and $0.5 \mathrm{~mL})$ water supplementation contributed to significant improvements of productive and reproductive performance, libido, and semen characteristics, as well as prophylactic alleviations of oxidative stresses in rabbit bucks.
\end{abstract}

Keywords | Nano-Selenium, Prophylactics, Rabbit bucks, Semen quality, Sexual behavior

Received | August 15, 2021; Accepted | September 06, 2021; Published | September 25, 2021

*Correspondence | Essam S. Soliman, Department of Animal Hygiene, Zoonosis and Animal Behavior, Faculty of Veterinary Medicine, Suez Canal University, Ismailia 41522, Egypt; Email: soliman.essam@vet.suez.edu.eg

Citation | Ali AA, Hassan ST, Soliman ES (2021). Leverage of nano-selenium on sexual behavior, reproductive performance, semen characteristics, and prophylactics in rabbit bucks at hot season. Adv. Anim. Vet. Sci. 9(11): 1908-1918.

DOI | http://dx.doi.org/10.17582/journal.aavs/2021/9.11.1908.1918

ISSN (Online) | 2307-8316; ISSN (Print) | 2309-3331

Copyright (C) $2021 \mathrm{Ali}$ et al. This is an open access article distributed under the Creative Commons Attribution License, which permits unrestricted use, distribution, and reproduction in any medium, provided the original work is properly cited.

\section{INTRODUCTION}

$\mathrm{R}_{\mathrm{i}, \mathrm{s}}^{\mathrm{a}}$ abbit breeders demand a sustained progressive increase in rabbit buck fertility that contributes to higher farm productivity, thus provide solutions to the animal protein shortage. Several obstacles might hinder the mass rabbit production like lowered buck fertility as a result of age and breed variations (Kheradmand and Babaei, 2006), reproductive pattern, health conditions (Castellini, 2008), mineral requirements (Mateos et al., 2010), feeding 
strategies (Pascual et al., 2016), and macroclimatic conditions like temperature, relative humidity, ventilation, lighting program, and hot seasons stress (Marai et al., 2002, 2008).

Trace elements supplementation in feed or water could improve rabbit buck sexual behavior and fertility (Ojha et al., 2018). Some researches were conducted to evaluate the influences of different trace elements supplementations on productive and reproductive performance in rabbits like manganese (Chen et al., 2020), copper (Kasperczyk et al., 2016), zinc (Kumar et al., 2006), and selenium; Se (Oda et al., 2012). Selenium plays an important role in biological processes and physiological functions (Kryukov et al., 2003). Selenium participates in the dynamics of lowering diseases development by enforcing a prophylactic influence against the activities of free radicals (Mohanty et al., 2018; Soetan et al., 2010). Moreover, Se is a component of enzymatic antioxidants like glutathione peroxidase (GPx) which is a group of selenium-dependent enzymes that plays a prophylactic role against lipid peroxidation (Skalickova et al., 2017), protects the cell membrane, and takes part in hydrogen peroxide $\left(\mathrm{H}_{2} \mathrm{O}_{2}\right)$ and lipids' hydroxy peroxide metabolism (Pan et al., 2018). Hence, Se improves animals' sexual behavior (Bhatt et al., 2017), reproduction (Mistry et al., 2012; Mehdi et al., 2013; Rezvanfar et al., 2013), and relieve stresses with high antioxidant capacity (Muller et al., 2002).

Selenium (organic or inorganic) has different forms that either possess low power against toxic metabolites and stresses ( $\mathrm{Li}$ et al., 2012) or produce highly toxic metabolites (Tarze et al., 2007). Nano-Selenium (NS) has an advantageous structure, high absorption capability, high bioavailability, increased catalytic efficiency, minimal energy loss, and increased surface activity (Ali et al., 2020). Nano-selenium provides functional benefits for rabbit buck like prophylactic influences against reproductive toxicity, improves the serum testosterone, enhances sperm quality, increases spermatogenesis, and reduces spermatic DNA damage (Broadway et al., 2015). Therefore, the usage and application of NS as an alternative for improving rabbit buck fertility contributed to lower toxicity and provide acceptable bioavailability (Peng et al., 2007; Wang et al., 2007).

The current study aims to investigate the prophylactic and augmenting influences of NS water supplementation at a dose of 0.5 and $1 \mathrm{~mL}$ of $100 \mathrm{mg} / \mathrm{L}$ and inorganic commercial selenium at a dose of $1 \mathrm{~mL}$ of $100 \mathrm{mg} / \mathrm{L}$ on rabbit bucks' productive and reproductive performance, libido, semen criteria, antioxidant levels, testosterone hormone, and cortisol hormone levels in the presence of hot season stress.

\section{MATERIALS AND METHODS}

\section{ETHICAL APPROVAL}

The Scientific Research Ethics Committee approved the study design, materials, methods, handling, and management procedures used in the current experiment with approval number (2021019).

\section{STUDY TIME AND LOCATION}

The study took place for 12 weeks from the beginning of the $2^{\text {nd }}$ week of May to the end of the $1^{\text {st }}$ week of August 2020. The current study was carried out in the Rabbit Research Unit, Teaching and Research Farm, Faculty of Veterinary Medicine, Suez Canal University, Ismailia, Egypt. The productive and reproductive indices, as well semen quality testing were carried out in the laboratories of faculty of Veterinary Medicine. Antioxidant and hormonal profiles were carried out in the Clinical Pathology laboratory, Suez Canal University Hospital, Ismailia, Egypt.

\section{SELENIUM AND NANO-SELENIUM PREPARATION}

Selenium inorganic form (Selenite-SEDICO ${ }^{\circledR}$ ) was purchased from a veterinary clinic in Ismailia Governorate, Egypt. Nano-selenium particles were prepared using selenium powder $\left(\mathrm{Merk}^{\oplus}\right)$ as a precursor and polyvinyl alcohol as a capping agent according to Hassan et al. (2020). The produced NS was crystalline and valid for six months. The concentration of selenium in both commercial and synthesized products was $100 \mathrm{mg} / \mathrm{L}$.

\section{Housing MANAGEMENT AND MICROCLIMATE}

The floor of the Rabbit Research Unit was cleaned and disinfected before the beginning of the study using water under pressure to remove any sticky organic matter, a mixture of quaternary ammonium compound and glutaraldehyde, water under pressure, brushing with sodium hydroxide $5 \%$ to increase the penetration power, fogging with formaldehyde, closure for $24 \mathrm{~h}$ for optimization of action, and ventilation for 24 to $48 \mathrm{~h}$ before rabbit's arrival. The removable objects were disinfected using potassium permanganate and hypochlorite 3\%. The units were enforced with some essential biosecurity measures like fly and rodents proof, foot dip at the entrance, proper cleaning measures, waste management, and secured water and feed resources as recommended by Soliman and Abdallah (2020). The units were ventilated naturally by side windows that stimulate and intensify the stack effect. The units were supplied with a continuous lighting program for $16 \mathrm{~h}$ light and $8 \mathrm{~h}$ of darkness using white LED lights (Soliman and Hassan, 2019).

\section{EXPERIMENTAL ANIMALS AND STUDY DESIGN}

Twenty-four (24) adult New Zealand White rabbit bucks of five months old with an average body weight of $2.960 \mathrm{~kg}$ 
were purchased from a commercial rabbit farm - Ismailia, Egypt. Rabbits on their arrival were individually housed in a battery flat-deck system (Soliman and Hassan, 2020). The cages were about $50 \times 60 \times 40 \mathrm{~cm}^{3}$ and made of galvanized iron with J-shape feeders and automatic stainless-steel nipple drinkers. Rabbit bucks were assigned into four equal groups of 6 bucks in a completely randomized design. Rabbits were supplied with $150 \mathrm{~g}$ of commercial pelleted diet per buck daily. The diet consisted of crude protein, digestible energy, and crude fiber at a rate of $17.78 \%$, $2525.2 \mathrm{Kcal} / \mathrm{Kg}$, and $10.21 \%$, respectively as recommended by the Nutrient Requirements of Rabbits (NRC, 1977).

\section{SELENIUM AND NANO-SELENIUM SUPPLEMENTATION}

The treatments were designed to be added per liter of drinking water. Rabbit bucks were treated as follows: the $1^{\text {st }}$ group (G1) was supplemented with one $\mathrm{mL}$ commercial inorganic Se (Selenite-SEDICO ${ }^{\oplus} 100 \mathrm{mg} / \mathrm{L}$ ), the $2^{\text {nd }}$ group (G2) was supplemented with $0.5 \mathrm{~mL}$ NS (100 $\mathrm{mg} / \mathrm{L}$ ), the $3^{\text {rd }}$ group (G3) was supplemented with 1.0 $\mathrm{mL}$ NS $(100 \mathrm{mg} / \mathrm{L})$, and the $4^{\text {th }}$ group (G4) was kept as control and supplied with clean un-supplemented water. The supplemented drinking water was provided daily for 12 weeks from the beginning of the experiment and going on.

\section{Productive PERFoRMANCE INDICES}

Live body weights were measured for all rabbit bucks at the start point of the experiment (Initial body weights, IBW/g), then weekly, as well as the final body weights at the end of the experiment (Final body weights, FBW/g). Body weights were measured using a digital scale (WONHENG ${ }^{\oplus}$ Computing Electronic Digital Counting Weight Balance Scale, $220 \mathrm{~V}, 30 \mathrm{~kg}$ ). Productive performance indices were calculated in weekly patterns as recommended by Soliman and Hassan (2017) like body weight gain (BWG/g) as the difference of the body weights at the end of each week from the body weights at the beginning of the same week for each group. Feed intakes (FI/g) were calculated by proportionating the amount of ration consumed by a group to the number of bucks in the same group. The feed conversion ratio was calculated by proportionating the feed intake $(\mathrm{g})$ to the weekly body weight gains $(\mathrm{g})$.

\section{LIBIDO TESTING AND SEMEN COLLECTION}

At the $10^{\text {th }}$ week, semen was collected by artificial vagina using a receptive female teaser rabbit. Sexual stimulation of the buck was achieved by leaving the doe on top of the buck's cage for few minutes to increases sperm concentration. The inner sleeve temperature of the artificial vagina was adjusted between $41-43^{\circ} \mathrm{C}$. Semen was collected twice weekly from each buck (A total of 144 samples, 2 times/ week $\times 3$ weeks $\times 24$ rabbit bucks). One ejaculate $(n=72)$ was assigned for the analysis of semen characteristics, while the other one $(n=72)$ was centrifuged at $3000 \mathrm{rpm}$ for 15 min (Fisher ${ }^{\circledR}$ Thermo Scientific CL10 Centrifuge w/ F-G3 Rotor with a max RPM of 4000), seminal plasma was harvested and stored at $-20^{\circ} \mathrm{C}$ until further analysis. The reaction time (RT) was recorded in seconds (sec) from the time at which the doe was placed within the buck's cage up to successful ejaculation and was considered as an indication of libido (Rodríguez-De Lara et al., 2010).

\section{REPRODUCTIVE PERFORMANCE INDICES}

Eight receptive nulliparous does were used for each group, each doe was matted by two bucks with 20 to 30 minutes intervals. Some reproductive criteria like kindling rate and litter size at birth (total and alive) and weaning were calculated. Kindling rate was also estimated using the following formula:

\section{Kindling rate $=($ The number of kindled does 1 the number of mated does) $\times 100$}

\section{SAMPLING}

Blood samples were harvested every two weeks from the auricular marginal vein using a $2.5 \mathrm{~mL}$ syringe fitted with a butterfly needle after the local application of an anesthetic cream $\left(\mathrm{EMLA}^{\varpi}\right)$.

Sera samples (A total of 120, 24 samples $\times 5$ times) were obtained from blood samples collected on serum vacutainer tubes (BD Vacutainer ${ }^{\varpi}$ Serum tubes, $10.0 \mathrm{~mL}$, $16 \times 100 \mathrm{~mm}$, Plastic, Additive: Clot Activator, Silicone Coated, Red Conventional Closure, and Paper Label). Samples were allowed to coagulate at room temperature for $2 \mathrm{~h}$, centrifuged at $3500 \mathrm{rpm}$ for $15 \mathrm{~min}$ (Fisher Thermo Scientific CL10 Centrifuge w/ F-G3 Rotor with a max RPM of 4000), pipetted into $2.5 \mathrm{~mL}$ Eppendorf tubes using an automatic pipette (Thermo Scientific ${ }^{\mathrm{TM}}$ Finnpipette $^{\mathrm{TM}}$ Adjustable Volume Single-Channel Micro Pipettor, 100 to $1000 \mu \mathrm{L}$ microliter Volume), and stored at $-20^{\circ} \mathrm{C}$ until further analysis (Soliman et al., 2017).

Plasma samples (A total of 120,24 samples $\times 5$ times) were obtained from blood samples collected on a whole blood vacutainer (VACUETTE ${ }^{\circledR}$ TUBE $5 \mathrm{ml}$ K3E K3EDTA 13x100 lavender cap-black ring), centrifuged immediately, pipetted into $2.5 \mathrm{~mL}$ Eppendorf tubes, and stored at $-20^{\circ} \mathrm{C}$ until further analysis.

\section{SEMEN ANALYsis}

Semen samples (72 samples) were evaluated immediately after collection. Semen volume (S. vol. / mL) was assessed using a transparent graduated collector tube with $0.1 \mathrm{~mL}$ optically visible intervals, after removal of both air bubbles and gel material. Semen $\mathrm{pH}$ (S. $\mathrm{pH})$ was determined immediately after collection using a $\mathrm{pH}$ cooperative paper ranging from 7 to 12 with 1 grade (Dual-Tint). 
Sperm mass activity (SMA) was determined by a hot stage binocular microscope at a magnification of x100 according to Jimoh and Ewuola (2019). The sperm mass activity (SMA) was scored subjectively on a scale of "+" to " ++++" according to the intensity of waves generated by the sperm cells.

Sperm motility (Sp. Motility, \%) was measured according to Ewuola and Egbunike (2010) in a drop of fresh diluted semen with sodium citrate $2.9 \%$ placed on a warmed slide at $37^{\circ} \mathrm{C}$ using a hot stage binocular microscope at a magnification of $\mathrm{x} 400$. Three different microscopic fields were examined for detecting sperm progressive forward motility \% (Elsayed et al., 2019).

Sperm concentration (Sp. Conc., 106/mL) was evaluated with the use of a new improved Neubauer hemocytometer (Boeckel Co., Germany) following Ewuola and Egbunike (2010). The percent of sperm viability and abnormalities were measured by staining a drop of each ejaculate with eosin/nigrosine stain and counting 200 sperms cells at a magnification of $x 400$ (E1-Desoky et al., 2017).

Some measures were calculated like Normal live sperm (NLS, \%), Abnormal live sperm (ALS, \%), Normal dead sperm (NDS, \%), Abnormal dead sperm (ADS, \%), and finally the normal alive motile sperm per ejaculate (NAM, million/ejaculate) was calculated from the following formula:

\section{$N A M=$ Sperm concentration $/ m L \times$ Volume $\times$ Motility $\times$ Normal alive sperm \%}

\section{ANTIOXIDANT ACTIVITY AND HORMONAL PROFILE}

Seminal plasma samples $(n=72)$ were analyzed for total glutathione activity (GSH, IU/L), Glutathione peroxidase (GHPx, mg/L), glutathione S-transferase (GST, IU/L), and superoxide dismutase (SOD, IU/L) using Roche Integra 400 Plus chemical analyzer. Plasma samples ( $\mathrm{n}=$ 120s) were analyzed for testosterone hormone expressed by $\mathrm{ng} / \mathrm{dL}$ as a biomarker of testicular function, as well as sera samples $(n=120)$, were analyzed for cortisol hormone expressed as $\mathrm{mcg} / \mathrm{dl}$ using ROCHE Elecsys 1010 Immunoassay Analyzer.

\section{STATISTICAL ANALYSIS}

The recorded data were analyzed using the statistical package for social sciences (SPSS version 21.0) software package (SPSS, 2016). The data were analyzed statistically using one-way ANOVA to determine the overall influence of Se and NS $(100 \mathrm{mg} / \mathrm{L})$ treatments at a dose of 1.0, 0.5, and $1.0 \mathrm{~mL} / \mathrm{L}$ drinking water, respectively on productive and reproductive performance, semen characteristics, antioxidant activity, testosterone hormone levels, and cortisol hormone levels in rabbit bucks. The statistical model empathized:

$$
Y_{i j}=\mu+\alpha_{j}+\varepsilon_{i j}
$$

Where $\mathrm{Y}_{\mathrm{ij}}$ was the measurement of dependent variables; $\mu$ was the overall mean; $\alpha_{j}$ was the fixed effect of the treatments, and $\varepsilon_{\mathrm{ij}}$ was the random error. Results were expressed for high significance at $(\mathrm{P}<0.01)$, significant at $(\mathrm{P} \leq 0.05)$, and non-significant at $(\mathrm{P}>0.05)$.

\section{RESULTS}

\section{Productive PERFORMANCE INDICES}

Initial body weights in Table 1 revealed non-significant differences between the supplemented rabbit bucks and the control group. Meanwhile, final body weight (Table 1) revealed highly significant $(P<0.01)$ increases in $G 3$ (1 mL NS/L) compared to the other supplemented bucks and the control.

Bodyweight gains (Table 1 ) revealed highly significant $(\mathrm{P}$ $<0.01)$ increases in G3 (1 mL NS/L), G2 (0.5 mL NS/L), and $\mathrm{G} 1(1 \mathrm{~mL} \mathrm{Se})$, respectively compared to the control.

Feed intakes in Table 1 revealed non-significant differences between the three supplemented groups and the control group. Feed conversion ratios revealed in Table 1 highly significant $(P<0.01)$ mathematical increases in $G 2(0.5$ $\mathrm{mL} \mathrm{NS/L})$ and $\mathrm{G} 3(1 \mathrm{~mL} \mathrm{NS} / \mathrm{L})$ with no significant differences between the two groups in FCR values.

\section{LIBIDO AND SEMEN CHARACTERISTICS}

Reaction time, sperm motility, sperm concentration, normal live sperm, abnormal live sperm, normal dead sperm, abnormal dead sperm, and normal alive motile sperm per ejaculate revealed in Table 2 highly significant $(\mathrm{P}<0.01)$ increases in G3 (1 mL NS/L), G2 (0.5 mL NS/L), and G1 $(1 \mathrm{~mL} \mathrm{Se})$, respectively compared to the control.

Sperm mass activity (Table 2) revealed significant $(\mathrm{P}<$ 0.01 ) increases in $\mathrm{G} 3(1 \mathrm{~mL} \mathrm{NS} / \mathrm{L})$ compared to other supplemented groups and control. Semen volume and $\mathrm{pH}$ in Table 2 revealed non-significant differences between the supplemented groups and the control group.

\section{REPRODUCTIVE PERFORMANCE INDICES}

Kindling rate, the total number of born kits per litter, and litter weight at birth revealed in Table 3 highly significant $(\mathrm{P}<0.01)$ increases in G3 $(1 \mathrm{~mL} \mathrm{NS} / \mathrm{L}), \mathrm{G} 2(0.5 \mathrm{~mL}$ $\mathrm{NS} / \mathrm{L}$ ), and G1 (1 $\mathrm{mL} \mathrm{Se})$, respectively compared to the control. The total number of alive-born kits per litter (Table 3) revealed highly significant $(P<0.01)$ increases in $G 2$ $(0.5 \mathrm{~mL} \mathrm{NS} / \mathrm{L})$ and $\mathrm{G} 3(1 \mathrm{~mL} \mathrm{NS} / \mathrm{L})$ with no significant differences between the two groups. 
Table 1: Productive performance (Mean \pm SE) in different rabbit groups exposed to environmental heat stress.

\begin{tabular}{|c|c|c|c|c|c|}
\hline Groups & IBW g & FBW g & BWG g & FI $g$ & FCR \\
\hline G1 & $2984^{\mathrm{a}} \pm 12.0$ & $4269.2^{c} \pm 33.0$ & $108.1^{\mathrm{c}} \pm 0.14$ & $475.6^{a} \pm 0.86$ & $4.3^{b} \pm 0.07$ \\
\hline G2 & $2964^{\mathrm{a}} \pm 11.0$ & $4316.4^{b} \pm 42.0$ & $112.7^{b} \pm 0.11$ & $464.5^{\mathrm{a}} \pm 0.59$ & $4.1^{\mathrm{a}} \pm 0.01$ \\
\hline G3 & $2952^{\mathrm{a}} \pm 10.0$ & $4361.52^{\mathrm{a}} \pm 56.0$ & $118.46^{\mathrm{a}} \pm 0.10$ & $477.8^{a} \pm 0.65$ & $4.0^{\mathrm{a}} \pm 0.01$ \\
\hline G4 & $2966^{\mathrm{a}} \pm 11.0$ & $4192.4^{\mathrm{d}} \pm 22.0$ & $102.2^{\mathrm{d}} \pm 0.13$ & $460.0^{a} \pm 0.56$ & $4.5^{c} \pm 0.09$ \\
\hline $\mathrm{P}$-value & 0.275 & $0.01^{* *}$ & $0.001^{* *}$ & 0.56 & $0.005^{* *}$ \\
\hline
\end{tabular}

Means carrying different superscripts in the same column are significantly different at $(\mathrm{P} \leq 0.05)$ or highly significantly different at $(\mathrm{P}<0.01)$. Means carrying the same superscripts in the same column are non-significantly different at $(\mathrm{P}<0.05)$. *: degree of significance. G1= Rabbit bucks supplemented with $1 \mathrm{~mL}$ inorganic commercial Se $(100 \mathrm{mg} / \mathrm{L})$ per liter drinking water, G2= Rabbit bucks supplemented with $0.5 \mathrm{~mL}$ synthesized NS (100 mg/L) per liter drinking water, G3=Rabbit bucks supplemented with $1.0 \mathrm{~mL}$ synthesized NS (100 mg/L) per liter drinking water, G4=control un-supplemented rabbit bucks. IBW=Initial body weights, FBW= Final body weights, BWG= Body weight gains, FI= Feed intakes, FCR= Feed conversion ratio, $\mathrm{SE}=$ Standard error.

Table 2: Libido and semen characteristics (Mean $\pm \mathrm{SE}$ ) in different rabbit groups exposed to environmental heat stress.

\begin{tabular}{|c|c|c|c|c|c|}
\hline \multirow[t]{2}{*}{ Semen characteristics } & \multicolumn{4}{|c|}{ Rabbit bucks' groups } & \multirow[t]{2}{*}{ P-value } \\
\hline & G1 & G2 & G3 & G4 & \\
\hline RT, sec & $11.4^{\mathrm{c}} \pm 0.17$ & $10.1^{\mathrm{b}} \pm 0.09$ & $8.6^{\mathrm{a}} \pm 0.13$ & $13.3^{\mathrm{d}} \pm 0.12$ & $0.01^{* *}$ \\
\hline S. vol., mL & $0.53^{a} \pm 0.01$ & $0.56^{\mathrm{a}} \pm 0.03$ & $0.57^{\mathrm{a}} \pm 0.02$ & $0.51^{\mathrm{a}} \pm 0.01$ & 0.34 \\
\hline S. pH & $7.18^{a} \pm 0.4$ & $7.17^{\mathrm{a}} \pm 0.6$ & $7.05^{\mathrm{a}} \pm 0.2$ & $7.13^{\mathrm{a}} \pm 0.1$ & 0.35 \\
\hline SMA & +++ & +++ & ++++ & ++ & $0.05^{*}$ \\
\hline Sp. motility (\%) & $70.8^{c} \pm 1.8$ & $71.5^{\mathrm{b}} \pm 1.2$ & $74.4^{\mathrm{a}} \pm 1.1$ & $61.4^{\mathrm{d}} \pm 1.7$ & $0.002^{* * *}$ \\
\hline Sp. Conc., 106/mL & $297^{c} \pm 17.3$ & $301^{\mathrm{b}} \pm 16.7$ & $306^{\mathrm{a}} \pm 13.5$ & $283^{\mathrm{d}} \pm 14.2$ & $0.01^{* *}$ \\
\hline NAS, $\%$ & $81.9^{b} \pm 1.7$ & $82.4^{\mathrm{b}} \pm 2.5$ & $86.0^{\mathrm{a}} \pm 3.1$ & $72^{c} \pm 1.3$ & $0.003^{* *}$ \\
\hline ALS, $\%$ & $7.2^{c} \pm 0.15$ & $6.4^{\mathrm{b}} \pm 0.21$ & $5.7^{\mathrm{a}} \pm 0.19$ & $7.8^{\mathrm{d}} \pm 0.24$ & $0.001^{* *}$ \\
\hline NDS, $\%$ & $1.9^{c} \pm 0.04$ & $3^{b} \pm 0.01$ & $1.3^{\mathrm{a}} \pm 0.02$ & $10.2^{\mathrm{d}} \pm 0.4$ & $0.001^{* *}$ \\
\hline $\mathrm{ADS}, \%$ & $9^{c} \pm 0.03$ & $8.2^{b} \pm 0.02$ & $7^{\mathrm{a}} \pm 0.01$ & $10^{\mathrm{d}} \pm 0.09$ & $0.001^{* * *}$ \\
\hline NAM, 10\%/ejacul. & $91.3^{c} \pm 4.7$ & $99.3^{\mathrm{b}} \pm 5.9$ & $111.6^{\mathrm{a}} \pm 7.2$ & $63.8^{\mathrm{d}} \pm 3.8$ & $0.01^{* *}$ \\
\hline
\end{tabular}

Means carrying different superscripts in the same row are significantly different at $(\mathrm{P} \leq 0.05)$ or highly significantly different at $(\mathrm{P}$ $<0.01)$. Means carrying the same superscripts in the same row are non-significantly different at $(\mathrm{P}<0.05)$. *: degree of significance. G1= Rabbit bucks supplemented with $1 \mathrm{~mL}$ inorganic commercial Se $(100 \mathrm{mg} / \mathrm{L})$ per liter drinking water, $\mathrm{G} 2=$ Rabbit bucks supplemented with $0.5 \mathrm{~mL}$ synthesized NS $(100 \mathrm{mg} / \mathrm{L})$ per liter drinking water, G3= Rabbit bucks supplemented with $1.0 \mathrm{~mL}$ synthesized NS (100 mg/L) per liter drinking water, G4= control un-supplemented rabbit bucks. RT= Reaction time, S. vol. = Semen Volume, S. pH= Semen pH, SMA= Sperm mass activity, Sp. motility=Sperm motility, Sp. Conc. = Sperm concentration, NAS= Normal live sperm, ALS=Abnormal live sperm, NDS=Normal dead sperm, ADS=Abnormal dead sperm, NAM=Normal alive motile, ejacul. $=$ Ejaculate, $\mathrm{SE}=$ Standard error .

\section{ANTIOXIDANT ACTIVITY AND HORMONAL PROFILE}

Seminal plasma antioxidant activity of total glutathione, glutathione peroxidase, superoxide dismutase, and glutathione S-Transferase revealed in Table 4 highly significant $(\mathrm{P}<0.01)$ increases in $\mathrm{G} 3(1 \mathrm{~mL} \mathrm{NS} / \mathrm{L}), \mathrm{G} 2$ (0.5 mL NS/L), and G1 (1 mL Se), respectively compared to the control.

Testosterone hormone revealed in Figure 1 highly significant $(\mathrm{P}<0.01)$ increases in $\mathrm{G} 3(1 \mathrm{~mL} \mathrm{NS} / \mathrm{L}), \mathrm{G} 2$ (0.5 mL NS/L), and G1 (1 mL Se), respectively compared to the control. Meanwhile, cortisol hormone revealed in Figure 2 highly significant $(\mathrm{P}<0.01)$ reductions in $\mathrm{G} 3$ (1 mL NS/L), G2 (0.5 mL NS/L), and G1 (1 mL Se), respectively compared to the control.

\section{DISCUSSION}

Rabbit production plays an important role in shortening the animal protein shortage in some countries (Khalil et al., 2016), as rabbit meat is advantageous for high protein, low cholesterol, better taste, and high nutritive quality (E1-Sabrout, 2018). Welfare with high productivity and fertility are the main points of interest in animal and poultry production, they can be achieved by optimizing the macro and microclimatic conditions of the animal or birds like temperature, relative humidity, housing location, and design, animal-human interrelationship, feeding and watering system, and functional and operational biosecurity measures (E1-Sabrout and Aggag, 2015). The normal behavior is known by the first attempt of an animal or bird to react to the surrounding friendly environment, but when the surrounding environment is hostile or 
presenting stressful conditions the behavior tends to deviate to vices (Gonçalves et al., 2017). In addition, the presence of heat stress exerts negative influences on rabbit productive and reproductive performance as a major challenge in subtropical regions, especially when combined with high humidity (El-Desoky et al., 2017). Therefore the present study was designed to clarify the role of NS and inorganic Se water supplementation regarding rabbit buck productive and reproductive performances, libido, semen criteria, antioxidant activity, testosterone, and cortisol levels in the presence of hot season stress.

Table 3: Reproductive performance (Mean \pm SE) in different rabbit groups exposed to environmental heat stress.

\begin{tabular}{lllll} 
Groups & \multicolumn{2}{l}{ Kind. rate \% T. kits / } & $\begin{array}{l}\text { Alive kits } \\
\text { litter }\end{array}$ & L. wt /birth g \\
G1 & $79.1^{\mathrm{b}} \pm 6.2$ & $7.5^{\mathrm{c}} \pm 0.7$ & $6.2^{\mathrm{b}} \pm 0.2$ & $49.6^{\mathrm{c}} \pm 4.2$ \\
G2 & $80.0^{\mathrm{b}} \pm 5.4$ & $8.1^{\mathrm{b}} \pm 0.5$ & $7.3^{\mathrm{a}} \pm 0.1$ & $62.4^{\mathrm{b}} \pm 3.1$ \\
G3 & $84.3^{\mathrm{a}} \pm 6.9$ & $8.9^{\mathrm{a}} \pm 0.7$ & $7.6^{\mathrm{a}} \pm 0.3$ & $65.3^{\mathrm{a}} \pm 4.3$ \\
G4 & $63.2^{\mathrm{c}} \pm 7.3$ & $6.2^{\mathrm{d}} \pm 0.6$ & $3.5^{\mathrm{c}} \pm 0.1$ & $35.4^{\mathrm{d}} \pm 2.3$ \\
P-value & $0.001^{* *}$ & $0.041^{*}$ & $0.024^{*}$ & $0.001^{* *}$
\end{tabular}

Means carrying different superscripts in the same column are significantly different at $(\mathrm{P} \leq 0.05)$ or highly significantly different at $(\mathrm{P}<0.01)$. Means carrying the same superscripts in the same column are non-significantly different at $(\mathrm{P}<0.05)$. *: degree of significance. G1= Rabbit bucks supplemented with $1 \mathrm{~mL}$ inorganic commercial Se (100 mg/L) per liter drinking water, $\mathrm{G} 2=$ Rabbit bucks supplemented with $0.5 \mathrm{~mL}$ synthesized NS $(100 \mathrm{mg} / \mathrm{L})$ per liter drinking water, G3= Rabbit bucks supplemented with $1.0 \mathrm{~mL}$ synthesized NS (100 mg/L) per liter drinking water, G4=control un-supplemented rabbit bucks. Kind. Rate $=$ Kindling rate, $\mathrm{T}$. kits/litter $=$ Total kits born per litter, alive kits/litter= Total kits born alive per litter, L. wt/birth= Litter weight at birth, $\mathrm{SE}=$ Standard error.

Table 4: Antioxidant activity (Mean \pm SE) in different rabbit groups exposed to environmental heat stress.

\begin{tabular}{|c|c|c|c|c|}
\hline Git & & g/L & /L & L \\
\hline II & & 17 & $28^{\mathrm{c}} \pm 0.18$ & 4 \\
\hline & & & & \\
\hline 3 & $10.1 \pm$ & $0.07=$ & 19 & o \\
\hline G4 & & & & \\
\hline & & & 0.011 & \\
\hline \multicolumn{5}{|c|}{$\begin{array}{l}\text { Means carrying different superscripts in the same column } \\
\text { are significantly different at }(\mathrm{P} \leq 0.05) \text { or highly significantly } \\
\text { different at }(\mathrm{P}<0.01) \text {. Means carrying the same superscripts in } \\
\text { the same column are non-significantly different at }(\mathrm{P}<0.05) \text {. } \\
\text { *: degree of significance. } \mathrm{G} 1=\mathrm{R} \text { Rabbit bucks supplemented with } \\
1 \mathrm{~mL} \text { inorganic commercial Se }(100 \mathrm{mg} / \mathrm{L}) \text { per liter drinking } \\
\text { water, } \mathrm{G} 2=\mathrm{Rabbit} \text { bucks supplemented with } 0.5 \mathrm{~mL} \text { synthesized } \\
\mathrm{NS}(100 \mathrm{mg} / \mathrm{L}) \text { per liter drinking water, } \mathrm{G} 3=\mathrm{Rabbit} \text { bucks } \\
\text { supplemented with } 1.0 \mathrm{~mL} \text { synthesized } \mathrm{NS}(100 \mathrm{mg} / \mathrm{L}) \text { per } \\
\text { liter drinking water, } \mathrm{G} 4=\text { control un-supplemented rabbit bucks. }\end{array}$} \\
\hline
\end{tabular}

GSH= Total glutathione activity, GHPx=Glutathione peroxidase, $\mathrm{SOD}=$ Super dismutase, $\mathrm{GST}=$ glutathione $\mathrm{S}$-transferase, $\mathrm{FCR}=$ Feed conversion ratio, $\mathrm{SE}=$ Standard error.

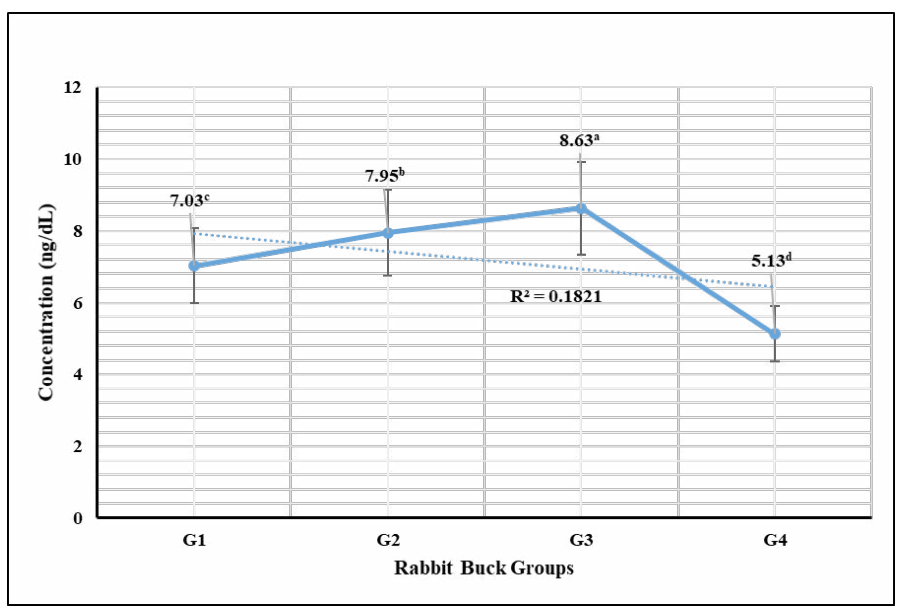

Figure 1: Testosterone hormone sera concentrations (Mean $\pm \mathrm{SE}$ ) expressed as $\mathrm{ng} / \mathrm{dL}$ in different rabbit groups exposed to environmental heat stress. G1= Rabbit bucks supplemented with $1 \mathrm{~mL}$ inorganic commercial Se $(100 \mathrm{mg} / \mathrm{L})$ per liter drinking water, G2= Rabbit bucks supplemented with $0.5 \mathrm{~mL}$ synthesized NS $(100 \mathrm{mg} / \mathrm{L})$ per liter drinking water, G3= Rabbit bucks supplemented with $1.0 \mathrm{~mL}$ synthesized NS $(100 \mathrm{mg} / \mathrm{L})$ per liter drinking water, G4= control un-supplemented rabbit bucks.

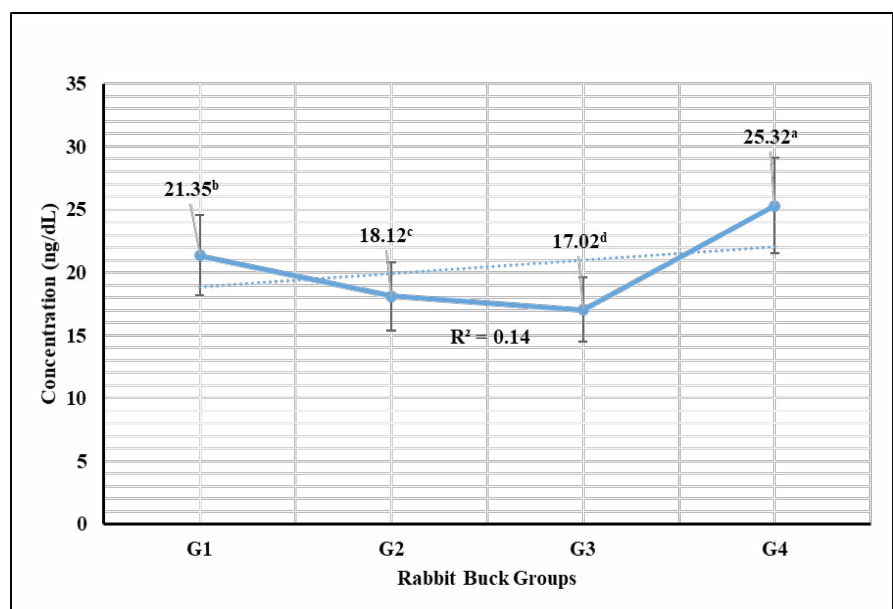

Figure 2: Cortisol hormone sera concentrations (Mean $\pm \mathrm{SE}$ ) expressed as $\mathrm{mcg} / \mathrm{dL}$ in different rabbit groups exposed to environmental heat stress. G1= Rabbit bucks supplemented with $1 \mathrm{~mL}$ inorganic commercial Se $(100 \mathrm{mg} / \mathrm{L})$ per liter drinking water; G2= Rabbit bucks supplemented with $0.5 \mathrm{~mL}$ synthesized NS $(100 \mathrm{mg} / \mathrm{L})$ per liter drinking water; G3= Rabbit bucks supplemented with $1.0 \mathrm{~mL}$ synthesized NS (100 mg/L) per liter drinking water; $\mathrm{G} 4=$ control un-supplemented rabbit bucks.

Controlled environmental houses for rabbits can optimize the microclimatic conditions and minimize the influences of the fluctuations in ecological and seasonal variations (Rodríguez-De Lara et al., 2010). Rabbits 
require calm, stable, friendly, and comfortable micro and macro-environmental conditions to live under to achieve maximum production and reproduction. Rabbit bucks under comfortable and friendly environmental conditions have greater sexual desire and higher semen production abilities (Nizza et al., 2003).

The current study revealed significant increases in the final body weights, bodyweight gains, and feed conversion ratios in rabbit bucks reared in the hot season and supplemented with $\mathrm{NS}$ at a rate of 0.5 and $1.0 \mathrm{~mL} / \mathrm{L}$ drinking water. These improvements might be attributed to the advantageous structure of NS that increases the absorption from the intestinal tract and bioavailability for the major biological processes and metabolism. The current results were consistent with those of AbdelWareth et al. (2019) and Barko et al. (2018) who reported significant increases in final body weights and weight gain, as well as a significant improvement in feed conversion ratios after NS supplementations in rabbits, compared to commercial Se. El-Sabrout and Shebl (2015) and Amer et al. (2019) also reported significant increases in weight gain of rabbits supplemented with $0.6 \mathrm{mg}$ sodium selenite/ $\mathrm{kg}$ diet and $0.6 \mathrm{mg}$ selenium-yeast $/ \mathrm{kg}$ diet compared with the control. Tag-El-Din (2019) and Borda-Molina et al. (2018) also recorded that the dietary supplementation of rabbits with trace elements like selenium can improve the gut conditions and intestinal microbiota contributing to significant absorption and enhanced performance. Belhassen et al. (2016) reported in a similar study that dietary supplementation with live yeast saccharomyces cerevisiae could progressively enhance growth performance, caecal ecosystem, and health of growing rabbits.

The study showed marked improvements in reaction time and semen characteristics, sperm motility, sperm concentration, normal live sperm, abnormal live sperm, normal dead sperm, abnormal dead sperm, normal alive motile sperm per ejaculate, and sperm mass activity in rabbit bucks supplemented with NS $(0.5$ and $1.0 \mathrm{~mL} / \mathrm{L})$ at the hot season. The current improvements might be attributed to the molecular structure and bioavailability of NS versus inorganic commercial Se to face the high demand of testes and epididymis of Se for the spermatogenesis process and thus the production of highly fertile sperm and semen of good characteristics. The results were in agreement with those of Abdel-Wareth et al. (2019) who reported positive improvements in semen quality after supplementing diets with NS $(400 \mu \mathrm{g} / \mathrm{kg})$ in rabbits. Moreover, sperm motility, morphology, and concentration were improved by $\mathrm{Se}$ supplementation as reported by Ewuola and Akinyemi (2017), Rezvanfar et al. (2013), and Mistry et al. (2012). Markovic et al. (2018) and Baiomy et al. (2009) also reported relevant positive improvements in libido and seminal traits after supplementing diets with Se in poultry.
El-Sabrout (2017) revealed the genetic capabilities of rabbit bucks to respond properly varies according to the surrounding microclimate, thus optimizing microclimate and supplementing diets with NS increased the genetic expressions for good seminal characteristics and higher sperm fertility in rabbit bucks.

The current results showed significant improvements in kindling rate, the total number of born kits per litter, litter weight at birth, and the total number of alive-born kits per litter in rabbit bucks supplemented with NS at a rate of 0.5 and $1.0 \mathrm{~mL} / \mathrm{L}$ in face of the hot season. The current results might be attributed to the improvement caused by NS supplementations in sperm fertility and semen quality including sperm concentration, viability (motility and livability), and morphology. The recorded results were supported by those of Theau-Clement and Roustan (1992) who reported that reproductive efficiency depends on semen quality of rabbit bucks, and when meets optimized environmental conditions and females of good physiological status contributed to significantly enhanced reproductive performance. Kamel (2012) reported that the selenium-folic acid supplementations contributed to improved seminal qualities and enhanced reproductive traits in rabbit bucks, as well as maintained efficient productive and reproductive performance in face of the hot summer season.

The antioxidant activity of total glutathione, glutathione peroxidase, superoxide dismutase, and glutathione S-Transferase in the current study revealed significant enhancement in rabbit bucks supplemented with NS at a rate of 0.5 and $1.0 \mathrm{~mL} / 1 \mathrm{~L}$ in face of the hot season. Brigelius-Flohé and Maiorino (2013) reported that glutathione peroxidases are a family of antioxidant enzymes. Their main function is to protect cells from the accumulation of $\mathrm{H}_{2} \mathrm{O}_{2}$ and they ensure the continued integrity of cell membranes. Their enzymatic activity is directly proportional to Se intake (Brigelius-Flohe et al., 1994; Brigelius-Flohé and Maiorino, 2013). The increased levels of Se in face of overwhelming challenges as heat stress, could protect the body from the harmful effect of reactive oxygen species on testes and semen quality as reported by Castellini et al. (2019). In that sense, Fairweather-Tait et al. (2010) reported that GPx-4 is important for sperm function and male fertility. Wang et al. (2007) reported that NS supplementation is important for the efficient functions of glutathione peroxidase (GHPx).

Testosterone hormone revealed significant increases in rabbit bucks reared at the hot season and supplemented with NS ( 0.5 and $1.0 \mathrm{~mL} / 1 \mathrm{~L})$. The high levels were achieved by the influence of NS on improving testicular tissue and enhancing spermatogenesis. These results were supported by Abdel-Wareth et al. (2019) and Ewuola and Akinyemi 
(2017) who reported that selenium supplementations have beneficial actions via improving the defense actions against reproductive toxicity, increasing the sera levels of testosterone, increasing sperm progressive movement, enhancing semen quality, increase the spermatogenesis process, and reduce the sperm DNA damage.

Stress marker cortisol hormone revealed significant reductions in rabbit bucks reared in the hot season and supplemented with NS $(0.5$ and $1.0 \mathrm{~mL} / 1 \mathrm{~L})$. The results were supported by those reported by Wadhwani et al. (2016), Ranawat and Bansal (2009), and Marai et al. (2008) who reported the significant actions of Se supplementation to enhance the antioxidant activity and in turn reduce the stress biomarkers like cortisol. Zhao et al. (2018) recorded similar results from NS supplementation in broiler breeders and their offspring. Soliman et al. (2020), Ahmadi et al. (2018), and Xiao et al. (2016) also reported the significant increase of serum immunoglobulin in the shadow of NS supplementation $(100 \mathrm{mg} / \mathrm{L})$ and mitigated the microbial challenges induced in the experiment.

\section{CONCLUSIONS AND RECOMMENDATIONS}

Nano-selenium supplementation in the drinking water of rabbit bucks at a rate of 0.5 and $1.0 \mathrm{~mL}$ of $100 \mathrm{mg} / \mathrm{L}$ per liter drinking water for 12 weeks in face of the hot season contributed to significant enhancement of productive traits (live body weights, weight gains, and feed conversion ratios) and reproductive traits (kindling rate, the total number of born kits per litter, litter weight at birth, and the total number of alive-born kits per litter).

Nano-selenium supplementation improved semen characteristics (reaction time, sperm motility, sperm concentration, normal live sperm, abnormal live sperm, normal dead sperm, abnormal dead sperm, normal alive motile sperms per ejaculate, sperm mass activity), and increased testosterone hormone. The significant enhancements were achieved by improving the action of NS in the antioxidant activity and reducing the stress marker cortisol hormone, thus mitigated the stress produced by the development of environmental heat stress of the hot season.

\section{ACKNOWLEDGMENTS}

Many thanks to Dr. O.M. Abdelmoniem, Nano Science and Technology Institute, Kafr El-Sheikh University, Kafr El-Sheikh, Egypt, for supplying selenium nanoparticles voluntarily. Also, we would like to express our thanks to the community services sector for the unit they provided to conduct our experiment.

\section{NOVELTY STATEMENT}

The research paper resides uniquely the pattern of nanoselenium water supplementation as a prophylactic, as well the augmentation of reproductive performance, semen quality, and sexual behavior in rabbit bucks exposed to high ambient temperature.

\section{AUTHOR'S CONTRIBUTION}

AAA designed the experimental design, supervised the in-vivo experiment, participated in the analysis of the samples, and took a part in writing the manuscript. STH co-supervised the in-vivo experiment, conducted the seminal analysis and reproduction performance, and took a part in writing the manuscript. ESS participated in the sera samples analysis and productive performance calculations, as well as took a part in writing the manuscript.

\section{CONFLICT OF INTEREST}

The authors have declared no conflict of interest.

\section{REFERENCES}

-Abdel-Wareth A, Ahmed A, Hassan H, Abd El-Sadek M, Ghazalah A, Lohakare J (2019). Nutritional impact of nano-selenium, garlic oil, and their combination on growth and reproductive performance of male Californian rabbits. Anim. Feed Sci. Technol., 249(2019): 37-45. https://doi. org/10.1016/j.anifeedsci.2019.01.016

-Ahmadi M,Ahmadian A, Seidavi AR (2018). Effect of different levels of nano-selenium on performance, blood parameters, immunity and carcass characteristics of broiler chickens. Poult. Sci., 6(1): 99-108.

-Ali AA, Soliman ES, Hamad RT, El-Borady OM, Hassan RA, Helal MS (2020). Preventive, behavioral, productive, and tissue modification using green synthesized selenium nanoparticles in the drinking water of two broilers breeds under microbial stress. Rev. Bras. de Ciência Avícola, 22(1): 1-16. https://doi.org/10.1590/1806-9061-2019-1129

- Amer AS, Omar AE, Abd El-Hack ME (2019). Effects of selenium- and chromium-enriched diets on growth performance, lipid profile, and mineral concentration in different tissues of growing rabbits. Biol. Trace Elem. Res., 187(1): 92-99. https://doi.org/10.1007/s12011-018-1356-4

-Baiomy A, Mohamed A, Mottelib A (2009). Effect of dietary selenium and vitamin $\mathrm{E}$ supplementation on productive and reproductive performance in rams. J. Vet. Med. Res., 19(1): 39-43. https://doi.org/10.21608/jvmr.2009.77807

-Barko PC, McMichael M.A, Swanson KS, Williams DA (2018). The gastrointestinal microbiome:A review. J. Vet. Int. Med., 32(1): 9-25. https://doi.org/10.1111/jvim.14875

-Belhassen T, Bonai A, Gerencsér ZS, Matics ZS, Tuboly T, Bergaoui R, Kovacs M (2016). Effect of diet supplementation with live yeast saccharomyces cerevisiae on growth performance, caecal ecosystem and health of growing rabbits. World Rabbit Sci., 24(3): 191-200. https:// doi.org/10.4995/wrs.2016.3991

- Bhatt RS, Agrawal AR, Sahoo A (2017). Effect of probiotic 
supplementation on growth performance, nutrient utilization and carcass characteristics of growing Chinchilla rabbits. J. Appl. Anim. Res., 45(1): 304-309. https://doi.org /10.1080/09712119.2016.1174126

-Borda-Molina D, Seifert J, Camarinha-Silva A (2018). Current perspectives of the chicken gastrointestinal tract and its microbiome. Computat. Struct. Biotechnol. J., 16(2018): 131-139. https://doi.org/10.1016/j.csbj.2018.03.002

-Brigelius-Flohe R, Aumann KD, Blöcker H, Gross G, Kiess M, Klöppel KD, Usani F (1994). Phospholipid-hydroperoxide glutathione peroxidase. Genomic DNA, cDNA, and deduced amino acid sequence. J. Biol. Chem., 269(10): 7342-7348. https://doi.org/10.1016/S0021-9258(17)37290-3

- Brigelius-Flohé R, Maiorino M (2013). Glutathione peroxidases. Biochimica et Biophysica Acta (BBA). Gen. Subjects, 1830(5): 3289-3303. https://doi.org/10.1016/j. bbagen.2012.11.020

- Broadway PR, Carroll JA, Sanchez NCB (2015). Live yeast and yeast cell wall supplements enhance immune function and performance in food-producing livestock: A review. Microorganisms, 3(3): 417-427. https://doi.org/10.3390/ microorganisms 3030417

- Castellini C (2008). Semen production and management of rabbit bucks, Proc. $9^{\text {th }}$ world rabbit congress, Verona, Italy, pp. 10-13. https://www.cabdirect.org/cabdirect/ abstract/20113318294

- Castellini C, Mattioli S, Signorini C, Cotozzolo E, Noto D, Moretti E, Brecchia G, Dal Bosco A, Belmonte G, Durand T (2019). Effect of dietary source on rabbit male reproduction. Oxid. Med. Cell. Longevity, Article ID 3279670. https:// doi.org/10.1155/2019/3279670

- Chen X, Yang G, Zhang B, Li F, Liu L, Li F (2020). Effects of manganese-supplemented diets on growth performance, blood biochemistry, nitrogen metabolism and skeletal development of rex rabbits. J. Trace Elem. Med. Biol., 61(September): 126543. https://doi.org/10.1016/j. jtemb.2020.126543

-El-Desoky N, Hashem N, Elkomy A, Abo-Elezz Z (2017). Physiological response and semen quality of rabbit bucks supplemented with Moringa leaves ethanolic extract during summer season. Animal, 11(9): 1549-1557. https://doi. org/10.1017/S1751731117000088

-El-Sabrout K (2017). Associations between single-nucleotide polymorphisms of melanocortin gene and sexual desire behaviour in rabbit (Oryctolagus cuniculus). J. Vet. Beh., 19(May to June): 69-71. https://doi.org/10.1016/j. jveb.2017.02.005

-El-Sabrout K (2018). Does the blindness affect the behavioural activities of rabbit? J. Anim. Behav. Biometeorol., 6(1): 6-8. https://doi.org/10.31893/2318-1265jabb.v6n1p6-8

-El-Sabrout K, Aggag SA (2015). Use of inter simple sequence repeats and protein markers in assessing genetic diversity and relationships among four rabbit genotypes. World Rabbit Sci., 23(4): 283-288. https://doi.org/10.4995/ wrs.2015.3912

-E1-Sabrout K, Shebl MK (2015). Effect of line and season on productive performance of rabbits. Int. J. Anim. Biol., 1(5): 182-186.

-Elsayed DH, El-Shamy AA, Abdelrazek HM, E1-Badry DA (2019). Effect of genistein on semen quality, antioxidant capacity, caspase-3 expression and DNA integrity in cryopreserved ram spermatozoa.Small Rum. Res.,177(2019): 50-55. https://doi.org/10.1016/j.smallrumres.2019.06.009
- Ewuola E, Egbunike G (2010). Effects of dietary fumonisin $\mathrm{B} 1$ on the onset of puberty, semen quality, fertility rates and testicular morphology in male rabbits. Reprod., 139(2): 439445. https://doi.org/10.1530/REP-09-0077

-Ewuola EO, Akinyemi DE (2017). Semen Characteristics of Rabbit Bucks Orally Administered Exogenous L-Selenomethionine. Ann. Res. Rev. Biol., 13(3): 1-8. https://doi.org/10.9734/ARRB/2017/19196

- Fairweather-Tait SJ, Collings R, Hurst R (2010). Selenium bioavailability: current knowledge and future research requirements. Am. J. Clin. Nutr., 91(5): 1484S-1491S. https://doi.org/10.3945/ajcn.2010.28674J

- Gonçalves S, Ferreira R, Pereira I, Oliveira C, Amaral P, Garbossa C, Fonseca L (2017). Behavioral and physiological responses of different genetic lines of free-range broiler raised on a semi-intensive system. J. Anim. Beh. Biometeorol., 5(4):112-117. https://doi.org/10.31893/2318-1265jabb. v5n4p112-117

-Hassan RA, Soliman ES, Hamad RT, El-Borady OM, Ali AA, Helal MS (2020). Selenium and nano-selenium ameliorations in two breeds of broiler chickens exposed to heat stress. South Africa. J. Anim. Sci., 50(2): 215-232. https://doi.org/10.4314/sajas.v50i2.5

- Jimoh OA, Ewuola EO. (2019). Semen characteristics and seminal oxidative status of four breeds of rabbit in South west, Nigeria. J. Basic Appl. Zool., 80(1): 1-9. https://doi. org/10.1186/s41936-019-0105-3

-Kamel I (2012). The effect of dietary organic selenium and folic acid supplementation on productive and reproductive performance of male rabbits under heat stress conditions. Egypt. Poult. Sci. J., 32(1): 43-62.

-Kasperczyk A, Dobrakowski M, Czuba ZP, Kapka-Skrzypczak L, Kasperczyk S (2016). Environmental exposure to zinc and copper influences sperm quality in fertile males. Ann. Agric. Environ. Med., 23(1): 138-143. https://doi. org/10.5604/12321966.1196869

- Khalil MH, Shebl MK, Kosba MA, El-Sabrout K, Zaki $N$ (2016). Estimate the contribution of incubation parameters influence egg hatchability using multiple linear regression analysis. Vet. World, 9(8): 806-810. https://doi, org/10.14202/vetworld.2016.806-810

- Kheradmand A, Babaei HJ (2006). Effect of ewe breed on the reaction time and semen characteristics in the ram. Iran. J. Vet. Res., 7(4): 23-26.

-Kryukov GV, Castellano S, Novoselov S, Lobanov A, Zehtab O, Guigo R, Gladyshev VN (2003). Characterization of mammalian selenoproteomes. Science, 300(5624): 14391443. https://doi.org/10.1126/science.1083516

- Kumar N, Verma RP, Singh LP, Varshney VP, Dass RS (2006). Effect of different levels and sources of zinc supplementation on quantitative and qualitative semen attributes and serum testosterone level in crossbred cattle (Bos indicus x Bos tarrus) bulls. Reprod. Nutr. Dev., 46(6): 663-675. https:// doi.org/10.1051/rnd:2006041

- Li J, Sun K, Ni L, Wang X, Wang D, Zhang J (2012). Sodium selenosulfate at an innocuous dose markedly prevents cisplatin-induced gastrointestinal toxicity. Toxicol. Appl. Pharmacol., 258(3): 376-383. https://doi.org/10.1016/j. taap.2011.11.020

- Marai IFM, Habeeb AAM, Gad AE (2002). Rabbits' productive, reproductive and physiological performance traits as affected by heat stress: A review. Livest. Prod. Sci., 78(2): 71-90. https://doi.org/10.1016/S0301-6226(02)00091-X 
- Marai IFM, Habeeb AAM, Gad AE (2008). Performance of New Zealand White and Californian male weaned rabbits in the subtropical environment of Egypt. Anim. Sci. J., 79(4): 472-480. https://doi.org/10.1111/j.17400929.2008.00552.x

- Markovic R, Ćirić J, Starčević M, Šefer D, Baltić MZ (2018). Effect of selenium source and level in diet on glutathione peroxidase activity, tissue selenium distribution, and growth performance in poultry. Anim. Hlth. Res. Rev., 19(2): 166176. https://doi.org/10.1017/S1466252318000105

- Mateos G, Rebollar P, De Blas C (2010). Minerals, vitamins and additives. In: de Blas C., Wiseman J., editors. Nutrition of the Rabbit, $2^{\text {nd }}$ ed., CAB International; pp. 119-150. https:// www.cabi.org/cabebooks/ebook/20103205027 https://doi. org/10.1079/9781845936693.0119

- Mehdi Y, Hornick JL, Istasse L, Dufrasne I (2013). Selenium in the environment, metabolism and involvement in body functions. Molecular, 18(3): 3292-3311. https://doi. org/10.3390/molecules18033292

- Mistry HD, Pipkin FB, Redman CW, Poston L (2012). Selenium in reproductive health. Am. J. Obstet. Gynecol., 206(1): 21-30. https://doi.org/10.1016/j.ajog.2011.07.034

- Mohanty PP, Panda N, Swain RK, Behura NC, Ray P, Sethi AK, Panigrahi S (2018). A Comparison between organic and inorganic selenium: Effect on bodyweight, laying performance, hatchability in broiler breeder. Int. J. Curr. Microbiol. Appl. Sci., 7(5): 173-179. https://doi. org/10.20546/ijcmas.2018.705.022

- Muller AS, PaLlauf J, Most E (2002). Parameters of dietary selenium and vitamin $\mathrm{E}$ deficiency in growing rabbits. J. Trace Elem. Med. Biol., 16(1): 47-55. https://doi. org/10.1016/S0946-672X(02)80008-6

- National Research Council (1977). Nutrient requirements of rabbits: Second revised edition, 1977. Washington, DC: The National Academies Press.

- Nizza A, Di Meo C, Taranto S (2003). Effect of collection rhythms and season on rabbit semen production. Reprod. Dom. Anim., 38(6): 436-439. https://doi.org/10.1046/ j.1439-0531.2003.00458.x

- Oda SS, El-Maddawy ZK (2012). Protective effect of vitamin $\mathrm{E}$ and selenium combination on deltamethrin-induced reproductive toxicity in male rats. Exp. Toxicol. Pathol., 64(78): 813-819. https://doi.org/10.1016/j.etp.2011.03.001

- Ojha L, Grewal S, Singh AK, Pal RP, Mir SH (2018). Trace minerals and its role on reproductive performance of farm animals. J. Entomol. Zool. Stud., 6(4): 1406-1409.

- Pan T, Liu T, Tan S, Wan N, Zhang Y, Li S (2018). Lower selenoprotein $t$ expression and immune response in the immune organs of broilers with exudative diathesis due to selenium deficiency. Biol. Trace Elem. Res., 182(2): 364372. https://doi.org/10.1007/s12011-017-1110-3

-Pascual JJ, Marco-Jiménez F, Martínez-Paredes E, Ródenas L, Fabre C, Juvero M, Cano JL (2016). Feeding programs promoting daily feed intake stability in rabbit males reduce sperm abnormalities and improve fertility. Theriogenol., 8(3): 730-737. https://doi.org/10.1016/j. theriogenology.2016.02.026

- PengD,ZhangJ,Liu Q,TaylorEW(2007).Size effect of elemental selenium nanoparticles (nano-Se) at supranutritional levels on selenium accumulation and glutathione S-transferase activity. J. Inorgan. Biochem., 101(10): 1457-1463. https:// doi.org/10.1016/j.jinorgbio.2007.06.021

- Ranawat P,Bansal M(2009).Apoptosis induced by modulation in selenium status involves p38 MAPK and ROS: implications in spermatogenesis. Mol. Cell. Biochem., 330(1-2): 83-95. https://doi.org/10.1007/s11010-009-0103-8

- Rezvanfar MA, Rezvanfar MA, Shahverdi AR, Ahmadi A, Baeeri M, Mohammadirad A, Abdollahi M (2013). Protection of cisplatin-induced spermatotoxicity, DNA damage and chromatin abnormality by selenium nanoparticles. Toxicol. Appl. Pharmacol., 266(3): 356-365. https://doi.org/10.1016/j.taap.2012.11.025

-Rodríguez-De Lara R, Noguez-Estrada J, Rangel-Santos R, García-Muñiz J, Martínez-Hernández P, Fallas-López M, Maldonado-Siman E (2010). Controlled doe exposure as biostimulation of buck rabbits. Anim. Reprod. Sci., 122(3-4): 270-275. https://doi.org/10.1016/j.anireprosci.2010.09.002

-Skalickova S, Milosavljevic V, Cihalova K, Horky P, Richtera L, Adam V (2017). Selenium nanoparticles as a nutritional supplement. Nutriation, 33(January 2017): 83-90. https:// doi.org/10.1016/j.nut.2016.05.001

- Soetan KO, Olaiya C, Oyewole O (2010). The importance of mineral elements for humans, domestic animals and plants: A review. Afr. J. Food Sci., 4(5): 200-222.

-Soliman ES, Abdallah MS (2020). Assessment of biosecurity measures in broiler's farms in the Suez Canal area Egypt using a seasonal prevalence of Salmonellosis. Vet. World, 13(4): 622-632. https://doi.org/10.14202/ vetworld.2020.622-632

- Soliman ES, Hamad RT, Ahmed A (2017). Prophylactic and immune modulatory influences of Nigella sativa Linn. in broilers exposed to biological challenge. Vet. World, 10(12): 1447-1455. https://doi.org/10.14202/ vetworld.2017.1447-1455

- Soliman ES, Hassan RA (2017). Evaluation of superphosphate and meta-bisulfide efficiency in litter treatment on productive performance and immunity of broilers exposed to ammonia stress. Adv. Anim. Vet. Sci., 5(6): 253-259.

-Soliman ES, Hassan RA (2019). Impact of lighting color and duration on productive performance and Newcastle disease vaccination efficiency in broiler chickens. Vet. World, 12(7): 1052-1059. https://doi.org/10.14202/ vetworld.2019.1052-1059

- Soliman ES, Hassan RA (2020). Influence of housing floor on air quality, growth traits, and immunity in broiler chicken farms. Adv. Anim. Vet. Sci., 8(9): 997-1008. https://doi. org/10.17582/journal.aavs/2020/8.9.997.1008

- Soliman ES, Mahmoud FF, Fadel MA, Hamad RT (2020). Prophylactic impact of nano-selenium on performance, carcasses quality, and tissues' selenium concentration using reversed-phase high-performance liquid chromatography during microbial challenge in broiler chickens. Vet. World, 13(9): 1780-1797. https://doi.org/10.14202/ vetworld.2020.1780-1797

-SPSS (2016). Statistical Packages of Social Sciences. Version 21 for windows. SPSS. Inc. USA.

-Tag-El-Din NTH (2019). Effect of dry live yeast inclusion in fattening rabbit diets on productive performance and digestibility of nutrients. Egypt. J. Rabbit Sci., 29(2): 219233. https://doi.org/10.21608/ejrs.2019.111161

- Tarze A, Dauplais M, Grigoras I, Lazard M, Ha-Duong NT, Barbier F, Blanquet S, Plateau P (2007). Extracellular production of hydrogen selenide accounts for thiol-assisted toxicity of selenite against Saccharomyces cerevisiae. J. Biol. Chem., 282(12): 8759-8767. https://doi.org/10.1074/jbc. M610078200 
-Theau-Clement M, Roustan A (1992). A study on relationships between receptivity and lactation in the doe, and their influence on reproductive performances. J. Appl. Rabbit Res., 15(1992): 412-421.

-Wadhwani SA, Shedbalkar UU, Singh R, Chopade BA (2016). Biogenic selenium nanoparticles: current status and future prospects. Appl. Microbiol. Biotechnol., 100(6): 2555-2566. https://doi.org/10.1007/s00253-016-7300-7.

-Wang H, Zhang J, Yu H (2007). Elemental selenium at nano size possesses lower toxicity without compromising the fundamental effect on selenoenzymes: comparison with selenomethionine in mice. Free Radical Biol.
Med., 42(10): 1524-1533. https://doi.org/10.1016/j. freeradbiomed.2007.02.013

-Xiao X, Yuan D, Wand YX, Zhan XA (2016). The protective effects of different sources of maternal selenium on oxidative stressed chick embryo liver. Biol. Trace Elem. Res., 172(1): 201-208. https://doi.org/10.1007/s12011-015-0541-y

-Zhao R, Li K, Wang J, Wang Y, Wu R, Zhan X (2018). Effects of different forms and levels of selenomethionine on productive performance and antioxidant status of broiler breeders and its offspring. Biol. Trace Elem. Res., 188(1): 1-7. https://doi.org/10.1007/s12011-018-1430-y 